\title{
REALIZACJA POWOŁANIA DO ŚWIĘTOŚCI JAKO WYRAZ MORALNEJ DOSKONAŁOŚCI CZŁOWIEKA W ADHORTACJI APOSTOLSKIEJ GAUDETE ET EXSULTATE
}

DOI: http://dx.doi.org/10.12775/TiCz.2020.003

Streszczenie. W najnowszej adhortacji apostolskiej papież Franciszek przypomina o powszechnym powołaniu do świętości we współczesnym świecie. W tym kontekście świętość jako nieodzowny element moralnej drogi prowadzącej do ewangelicznej doskonałości stanowi przedmiot teologicznomoralnej refleksji i to bez względu na czas, w którym toczy się dyskusja. Jeszcze większy obszar wyzwań obejmuje praktyczne wcielenie jej w życie człowieka.

Wezwanie do świętości jest aktualne także dzisiaj i stanowi kluczowy aspekt życia członków Chrystusowego Kościoła w XXI wieku. W Gaudete et exsultate papież przywołuje ten fundamentalnym wymiarze ludzkiej egzystencji, wpisując go w ramy współczesnego świata. Biorąc na poważnie wskazania płynące z papieskiej zachęty, warto przyjrzeć się zagadnieniu świętości w dobie obecnej.

Artykuł stanowi próbę podjęcia refleksji nad kwestią świętości, odczytując realizację powołania do niej jako wyraz moralnej doskonałości człowieka, gdyż świętość nierozerwalnie wpisana została w wymagania płynące ze wskazań teologii moralnej.

Słowa kluczowe: Gaudete et exsultate; świętość; moralna doskonałość człowieka; papież Franciszek.

Abstract. Implementation of the Call to Holiness as an Expression of the Moral Perfection of Man. Based on the Apostolic Exhortation Gaudete et exsultate. 
In his newest apostolic exhortation, Pope Francis recalls the universal call to holiness in the modern world. In this context, holiness, as an indispensable element of the moral path, leads to evangelical perfection, and is the subject of theological and moral reflections, regardless of the time in which the discussions unfold. An even larger area of challenges include practical implementation of it in human life.

The call to holiness is also valid today, and is a key aspect of the life of the members of Christ's Church in the 21st century. In, Gaudete et exsultate, the Pope invokes this fundamental dimension of human existence by inscribing it into the framework of our modern world. The Pope indicates here his encouragement regarding the issue of holiness in our present era, and it is therefore worth taking seriously.

This article is an attempt to reflect on the question of holiness, reading the implementation to this call as an expression of the moral perfection of man, because sanctity was inseparably written into the requirements of moral theology.

Keywords: Gaudete et exsultate; Holiness; moral perfection of man; pope Francis.

Świętość jako nieodzowny element moralnej drogi prowadzącej do ewangelicznej doskonałości nieustannie stanowi przedmiot teologicznej refleksji i to bez względu na czas, w którym toczy się dyskusja. Jeszcze większy obszar wyzwań obejmuje praktyczne wcielenie jej w życie człowieka. O ile można ją poddać dogłębnemu badaniu i zamknąć w ramach usystematyzowanego traktatu „Z wieloma definicjami i rozróżnieniami, które mogłyby ubogacić ten ważny temat, lub z analizami, które można by przeprowadzić odnośnie do dróg uświęcenia", o tyle jako dojrzały, pragmatyczny i moralny imperatyw codziennego życia często wymyka się encyklopedycznym regułom. Nie oznacza to bynajmniej, że próby zdefiniowania świętości nie zostały podjęte. Jan Paweł II, mówiąc o świętości, podkreślał jej wymiar ontologiczny i moralny. Świętość ontologiczną wyznawca Chrystusa przyjmuje poprzez chrzest, a „dzięki łasce uświęcającej staje się nowym stworzeniem”2. Ten wymiar świętości swoją naturę czerpie z ontologicznego zakorzenienia w Bogu. Z kolei świętość w drugim aspekcie jest integralnie złączona z życiem moralnym człowieka, który „dzięki

${ }^{1}$ Franciszek, Adhortacja apostolska o powołaniu do świętości w świecie współczesnym „Gaudete et exsultate”, 2. Odtąd skrót: GE.

${ }^{2}$ Jan Paweł II, Powołanie do pełni życia chrześcijańskiego, w: tenże, Dzieła Zebrane, t. XV, Kraków 2009, s. 415. 
osobistym staraniom i pomocy, której Bóg nigdy nie odmawia”3 ${ }^{3}$ wezwany jest do jej ustawicznego wzrostu. Świętość ontologiczna, obiektywna zawiera w sobie obowiązek podjęcia wysiłku, który prowadzi do świętości moralnej, czyli „«wysokiej miary» zwyczajnego życia chrześcijańskiego”4. Świętość dotyka człowieka, wpisuje się w jego naturalną dążność duchowego i moralnego rozwoju. A „jako że w centrum teologii moralnej znajduje się właśnie człowiek, jego osobowa godność oraz to, jak ujawnia się ona i poświadcza w działaniu"5, to realizacja powołania do świętości staje się zadaniem, od którego nie można się dyspensować.

Wezwanie do świętości jest aktualne także dzisiaj i stanowi kluczowy aspekt życia członków Kościoła w XXI wieku. W swojej najnowszej adhortacji Gaudete et exsultate papież Franciszek przypomina o tym fundamentalnym wymiarze ludzkiej egzystencji, wpisując go w ramy współczesnego świata. Biorąc na poważnie wskazania płynące z papieskiej zachęty, warto przyjrzeć się zagadnieniu świętości w dobie obecnej. Artykuł stanowi próbę podjęcia refleksji nad kwestią świętości, odczytując realizację powołania do niej jako wyraz moralnej doskonałości człowieka, gdyż świętość nierozerwalnie wpisana została w wymagania płynące ze wskazań teologii moralnej.

\section{NATURA, CHARAKTER I OKOLICZNOŚCI POWSTANIA DOKUMENTU}

"Cieszcie się i radujcie” (Mt 5, 12) - tymi słowami, zaczerpniętymi z Ewangelii według św. Mateusza, papież Franciszek otwiera adhortację o powołaniu do świętości, wskazując, że widocznym jej owocem jest życie „z radosną wdzięcznością za ten dar”. Warto zauważyć, że tym zabiegiem papież kontynuuje podjętą $\mathrm{w}$ dwóch poprzednich adhortacjach próbę przywrócenia i dowartościowania chrześcijańskiej radości. „Radość

3 Tamże.

4 Tenże, List apostolski „Novo millennio ineunte”, 31.

${ }^{5}$ K. Demmer, Wprowadzenie do teologii moralnej, tłum. A. Baron, Kraków 1996, s. 12.

${ }^{6} \mathrm{GE}, 54$. 
Ewangelii” (Evangelii gaudium) oraz „Radość miłości” (Amoris laetitia) to zwroty rozpoczynające dwie poprzednie papieskie adhortacje i jednocześnie ich łacińskie tytuły. Podobnie jak w przypadku głoszenia Ewangelii oraz miłości w rodzinie, tak również w odniesieniu do świętości, radość stanowi istotny element życia w pełni chrześcijańskiego. Papież podkreśla, że „święty jest zdolny do życia pełnego radości i poczucia humoru".

Interesujący jest także charakter przedstawionego tekstu. W najnowszej adhortacji papieża Franciszka na próżno szukać naukowych dociekań, skrupulatnych i drobiazgowych rewizji, czy też teoretycznych wykładni na temat świętości. Dokument ma charakter pastoralny o istotnym zabarwieniu duszpasterskiej troski i nie chodzi w nim o precyzowanie, czy definiowanie jakichkolwiek kwestii doktrynalnych. Już na samym początku zachęty papież odcina się od takiego ujęcia podejmowanego zagadnienia, zaznaczając, że jego „skromnym celem jest przedstawienie po raz kolejny powołania do świętości, próbując ująć je w aktualnym kontekście, z jego zagrożeniami, wyzwaniami i możliwościami” ${ }^{10}$. Posługuje się przy tym językiem prostym, łatwym, nieskomplikowanym i przystępnym dla każdego, czerpiąc z siły oddziaływania świętych i ich przeżywania ewangelicznych błogosławieństw, które zawierają „słowa krótkie, proste, ale praktyczne i ważne dla wszystkich" ${ }^{\prime 1}$. Zgłębiając tekst i kartkując kolejne strony dokumentu, czytelnik odkrywa głębokie pragnienie i troskę papieża o to, aby wskazania płynące z kolejnych punktów adhortacji dotarły do każdego człowieka, stając się skutecznym narzędziem w rękach współczesnych uczniów Chrystusa, którzy na wzór swoich poprzedników wezwani są do tego, aby „wyruszyli we wszystkich kierunkach"12.

Osobliwe są również okoliczności wydania dokumentu. W odróżnieniu od Evangelii gaudium i Amoris laetitia, które stanowiły kolejno owoce Synodu Biskupów, najpierw o nowej ewangelizacji, a później o rodzinie, Gaudete et exsultate nie ma charakteru post-synodalnego.

${ }^{7}$ Franciszek, Adhortacja apostolska o głoszeniu Ewangelii we współczesnym świecie „Evangelii gaudium”, 1. Odtąd skrót: EG.

${ }^{8}$ Franciszek, Adhortacja apostolska o miłości w rodzinie „Amoris laetitia”, 1.

9 GE, 122.

$10 \mathrm{GE}, 2$.

11 GE, 109.

12 GE, 136. 
Rozszerzenie zwyczajnego nauczania papieża bez uprzedniego udziału i dyskusji biskupów to sytuacja, która w Kościele zdarza się bardzo rzadko. Ostatnio miała ona miejsce w przypadku pochylenia się nad osobą świętego Józefa oraz jego posłannictwie w życiu Chrystusa i Kościoła, czyli adhortacji apostolskiej Jana Pawła II Redemptoris custos wydanej w 1989 roku. Problematyka świętości okazuje się na tyle ważnym tematem dla Franciszka, że sam, bez konieczności zwoływania synodu, zdecydował się na opracowanie dokumentu o tak wysokiej randzie. Te nadzwyczajne uwarunkowania poprzedzające ogłoszenie Gaudete et exsultate dają prawo sądzić, że jest to osobista inicjatywa papieża z Argentyny, który tym samym pragnie przybliżyć ludowi Bożemu naszych czasów tak doniosły temat, jakim jest świętość w codzienności.

Ponadto warto zwrócić uwagę na styl i język, jakim w dokumencie posługuje się papież. Daleki jest on od oficjalnego pisma urzędowego, niewiele $\mathrm{w}$ nim dostojności, trudno doszukiwać się patetycznych sformułowań, stosowania doniosłych tytułów i zwrotów grzecznościowych. Franciszek często zwraca się do powierzonych jego duszpasterskiej pieczy wiernych i jednocześnie adresatów adhortacji w drugiej osobie liczby pojedynczej, podając konkretne wskazania do realizacji. Zastosowanie tak bezpośrednich zwrotów, jak: „pozwól, by łaska twego chrztu owocowała na drodze świętości”"13, „nie bój się świętości” ${ }^{14}$ czy „nie lękaj się dążyć wyżej” ${ }^{15}$, wskazuje na szczególną zażyłość oraz poczucie braterstwa, na które pozwolić mogą sobie tylko najwięksi przyjaciele. Dodatkowo używając zwrotów w pierwszej osobie liczy mnogiej, takich jak: „potrzebujemy ducha świętości”16, „bądźmy jednak uważni”17, „musimy być czujni i walczyć"18, papież nie tylko pokazuje, że nie stoi gdzieś daleko, odcięty od problemów współczesnego człowieka, ale że całkowicie identyfikuje się z tymi, ku którym adresuje swoje nauczanie, ugruntowując więź i duchową wspólnotę z nimi. To praktyczna realizacja słów Pawła VI,

\footnotetext{
13 GE, 15.

14 GE, 32.

15 GE, 34.

16 GE, 31.

17 GE, 39.

18 GE, 114.
} 
który podkreślał, że „człowiek naszych czasów chętniej słucha świadków aniżeli nauczycieli" ${ }^{19}$. Tym samym po raz kolejny Franciszek udowadnia, że zależy mu na bliskości z powierzonym ludem, że jako namiestnik Chrystusa i Pasterz Kościoła sam daje świadectwo i pragnie być pasterzem „o zapachu owiec" 20 .

\section{UNIWERSALIZM POWOŁANIA DO ŚWIĘTOŚCl}

Już w pierwszym rozdziale Gaudete et exsultate Franciszek podkreśla powszechny charakter powołania do świętości, wskazując na jej uniwersalizm, który obejmuje wszystkich wyznawców Chrystusa. Z całą mocą uwydatnia, że pragnie „przede wszystkim przypomnieć o powołaniu do świętości, które Pan kieruje do każdego z nas, o tym wezwaniu, które kieruje też do ciebie"21.

W tym stwierdzeniu papież kontynuuje linię nakreśloną przez Sobór Watykański II, który w Konstytucji Lumen gentium w bardzo podobnych słowach mówi, że „wszyscy chrześcijanie jakiegokolwiek stanu i zawodu powołani są do pełni życia chrześcijańskiego i do doskonałości miłości”22. Jeszcze bardziej oddaje to stwierdzenie, gdy Sobór podkreśla, że „wszyscy w Kościele, niezależnie od tego, czy należą do hierarchii, czy są przedmiotem jej funkcji pasterskiej, powołani są do świętości”23. Skądinąd cały V rozdział Lumen gentium został zadedykowany powszechnemu powołaniu do świętości w Kościele ${ }^{24}$. Ojcowie Soborowi, nauczając o świętości i jej uniwersalnym charakterze mieli na względzie „przede wszystkim świętość moralną, która jest zupełnie innym rodzajem życia niż to, jakie człowiek może prowadzić o własnych siłach. Być powołanym

19 Pawła VI, Przemówienie do członków „Concilium de Laicis”, AAS 66 (1974), s. 568; por. także: Pawła VI, Evangelii nuntiandi, nr. 41.

${ }^{20}$ Franciszek, $Z$ ludem na ramionach. Homilia wygłoszona podczas Mszy św. Krzyżma, „L'Osservatore Romano” wyd. pol. 371 (2015) 5, s. 35.

${ }^{21} \mathrm{GE}, 10$.

${ }^{22}$ Sobór Watykański II, Konstytucji dogmatyczna o Kościele „Lumen gentium”, n. 40. Odtąd skrót: KK.

$23 \mathrm{KK}, 39$.

${ }^{24}$ Por. KK, 39-42. 
do świętości, to być powołanym do życia, które jest w pewnym stopniu udziałem w życiu samego Boga" ${ }^{25}$. Mowa jest tutaj o Bogu, który jest źródłem wszelkiej świętości, ale z owej świętości ontologicznej ma wynikać świętość moralna, zdobywana poprzez trud, wysiłek i ciągłą potyczkę, gdyż „nasza droga do świętości jest nieustanną walką" ${ }^{26}$. Świętość, która w pierwszej kolejności przynależy do Boga, stanowiąc Jego atrybut, jest udzielana człowiekowi mocą Ducha Świętego przez Boga w Chrystusie. A zatem świętość moralną, ku której jest wezwany chrześcijanin, urzeczywistnia on poprzez uczestnictwo w świętości samego Chrystusa. Przywołując słowa swojego poprzednika, papieża Benedykta XVI, Franciszek wskazuje, że „miarą świętości jest to, jak wiele jest w naszym życiu z Chrystusa, oraz na ile, mocą Ducha Świętego, kształtujemy nasze życie na podobieństwo Jego życia"27. Poza tym nikt nie znajduje się poza powołaniem do świętości i nikt nie może czuć się z niego wyłączony, gdyż „Duch Święty rozlewa świętość wszędzie w świętym i wiernym ludzie Bożym" ${ }^{28}$. Ostatecznie papież utożsamia świętość z doskonałością w miłości i przeżywaniem tajemnic swojego życia z Chrystusem ${ }^{29}$, wpisując ją w ramy szczególnego nakazu moralnego wyrastającego z tajemnicy łaski chrztu ${ }^{30}$. Ofiarowana człowiekowi jako dar w łasce chrztu świętość ontyczna stanowi zadanie i jednocześnie staje się podstawą do urzeczywistniania jej wymiaru moralnego.

W świecie współczesnym, który często nosi znamiona świata egoistycznego, „Z zasadzkami i pokusami diabła” ${ }^{11}$, z mentalnością, jaka ogłupia, zwodzi i sprawia, „że jesteśmy mierni, pozbawieni zaangażowania i radości”32 powszechne powołanie do świętości staje się nieodzownym determinantem, przypominającym wiernym o wpisanym $\mathrm{w}$ ich naturę

25 P. Wróblewski, Świętość fundamentem odnowy Kościoła: powszechne powołanie do świętości, „Łódzkie Studia Teologiczne” 24 ( 2015) 3, s. 164.

${ }^{26} \mathrm{GE}, 162$

${ }^{27}$ GE, 21, Benedykt XVI, Wszyscy święci papieża, „L'Osservatore Romano” wyd. pol. 334 (2011) 6, s. 52 .

${ }^{28} \mathrm{GE}, 6$.

29 Por. GE, 20.

30 Por. GE, 15.

$31 \mathrm{GE}, 140$.

32 GE, 159. 
wymogu podjęcia wyzwania i roli jako sól ziemi i światło świata ${ }^{33}$. Gaudete et exsultate nie rości sobie prawa do bycia dokumentem mówiącym o beatyfikacji i kanonizacji, ale przybiera postać duchowego przewodnika dla wszystkich ludzi żyjących w obecnym czasie. Związane z tym wymagania moralne odbijają się w papieskim dokumencie z całą swoją precyzją. Summus Pontifex przypomina i równocześnie przestrzega przed tym, aby współcześni uczniowie szkoły Jezusa z Nazaretu nie pojmowali świętości jako wartości zarezerwowanej tylko dla wybranych. Przeciwnie, stoi na stanowisku, że każdy jest powołany do tego, aby realizować świętość w swoim codziennym życiu, stawiając czoła decyzją moralnym, które na niego czekają:

Aby być świętymi, nie trzeba być biskupami, kapłanami, zakonnikami ani zakonnicami. Często mamy pokusę, aby sądzić, że świętość jest zarezerwowana tylko dla tych, którzy mają możliwość oddalenia się od zwykłych zajęć, aby poświęcać wiele czasu modlitwie. Ale tak nie jest. Wszyscy jesteśmy powołani, by być świętymi, żyjąc z miłością i dając swe świadectwo w codziennych zajęciach, tam, gdzie każdy się znajduje ${ }^{34}$.

Świętość oraz wypływające z niej powinności moralne odzwierciedlają się w zwyczajnym działaniu i małych sprawach, które każdego dnia podejmuje ten, kto zdecydował się podążać za Jezusem. Bez względu na to, jaki stan życia prowadzi, czy jak powie Sobór - „we właściwym sobie stanie życia" 35 - cechą charakterystyczną chrześcijanina jest wierność swojemu powołaniu i to niezależnie od jego wielkości. Mimo że w tekście zaproponowanym przez papieża nie znajdziemy odwołania do postawy wielkiego polskiego świętego, jakim był św. Maksymilian Maria Kolbe choć Franciszek powołuje się na przykłady innych świętych, których wydała polska ziemia, wspominając św. Faustynę Kowalską (por. GeE, 121) i św. Jan Paweł II (por. GeE, 9, 45, 91, 96) - to w tej sytuacji warto przytoczyć słowa założyciela Niepokalanowa, dla którego świętość nie polegała na spełnianiu wielkich rzeczy, ale na „wykonywaniu punktualnym i sumiennym drobnych rzeczy, nie na długich modlitwach i umartwie-

\footnotetext{
33 Por. GE, 33

$34 \mathrm{GE}, 14$.

$35 \mathrm{KK}, 39$.
} 
niach, ale na dokładnym spełnianiu woli Bożej”36. Franciszkanin dalej rozwinął tą myśl:

W drobnych małych rzeczach należy się zabrać do pracy nad sobą. Jeżeli te drobne rzeczy zaniedbujemy, Pan Bóg nie da innych łask z miłosierdzia, aby się one nie marnowały i nie powiększały naszego długu wobec niego. Za każdą łaskę zdamy rachunek, czyśmy jej dobrze odpowiedzieli. Trzeba uważać na niewierności w drobnych rzeczach, bo one prowadzą do większych wykroczeń, a nawet do utraty powołania ${ }^{37}$.

Ostatecznie wierność sprawom małym zalecał sam Chrystus, obiecując wielką nagrodę tym, którzy sumiennie wywiązują się ze swoich zadań i obowiązków: „Dobrze, sługo dobry i wierny! W małej rzeczy byłeś wierny, nad wieloma cię postawię. Wejdź do radości twojego pana” (Mt 25, 21). W kontekście Jezusowego wezwania do świętości z większą jasnością można odczytać słowa Franciszka, który stwierdza, iż „świętość, do której wzywa cię Pan, będzie wzrastała przez małe gesty" ${ }^{38}$. Chodzi zatem o normalność, zwyczajność, w której w niezwykły sposób odbija się wyraźnie moralny blask świętości. Wiąże się to $\mathrm{z}$ nieuniknioną potrzebą właściwego rozeznania, rozumianego jako skuteczne narzędzie na drodze naśladowania Chrystusa. Zdaniem papieża „rozeznanie jest konieczne nie tylko w chwilach nadzwyczajnych lub gdy trzeba rozwiązać poważne problemy, czy też gdy trzeba podjąć kluczową decyzję"39, ale przede wszystkim materializuję się ono „w małych rzeczach, w tym, co wydaje się nieistotne, ponieważ wielkoduszność przejawia się w sprawach prostych i codziennych" ${ }^{40}$. Tego rodzaju postawę papież określa mianem „świętości z sąsiedztwa"41 lub - powołując się na twórczość francuskiego pisarza Josepha Malègue - „klasą średnią świętości”"42, która wyraża się

${ }^{36}$ M.M. Kolbe, Nasze radości i niedociagnięcia, w: Konferencje świętego Maksymiliana Marii Kolbego, red. J.R. Bar, Niepokalanów 2009, s.93.
37 Tamże.
38 GE, 16.
39 GE, 169.
40 Tamże.
${ }^{41} \mathrm{GE}, 7$.
42 Tamże. 
w sposobie postępowania osób żyjących tuż obok nas poprzez odbicie blasku obecności samego Boga ${ }^{43}$.

Prezentując praktyczne wskazania, które mówią jak być świętym we współczesnym świecie, Franciszek czerpie z bogatego skarbca świętych Kościoła. I tak znaleźć możemy odwołanie do św. Teresa z Lisieux, w której stylu świętości objawia się kobiecy geniusz „niezbędny do odzwierciedlenia świętości Boga na tym świecie" ${ }^{4}$. Święta Teresa od Dzieciątka Jezus stanowi wzór świętości odnaleziony w spełnianiu drobnych uczynków naznaczonych ewangeliczną miłością wobec bliźniego. Papież przypomina, że dla niej świętość była równoznaczna z miłością doskonałą, która polegała na tym, „by znosić wady innych, by nie dziwić się wcale ich słabościom" ${ }^{45}$. Kolejny przywołany święty to św. Ignacy z Loyoli, który starał się odnaleźć Boga w każdej rzeczy i który proponuje człowiekowi XXI wieku świętość związaną z odtwarzaniem „w swoim życiu różnych aspektów ziemskiego życia Jezusa: Jego życia ukrytego, życia wspólnotowego, Jego bliskości względem ostatnich, Jego ubóstwa oraz innych przejawów Jego dawania siebie ze względu na miłośc" "46. Podjęcie rzetelnej i dogłębnej refleksji nad misterium życia Zbawiciela prowadzi do implementacji słusznych postaw moralnych w codzienności, w której dzisiejszy człowiek niejednokrotnie czuje się zagubiony. Odpowiednim drogowskazem podjęcia właściwej ścieżki na drodze wzrostu moralnego wydaje się epitafium, jakie zostało wyryte na grobie św. Ignacego Loyoli „Non coerceri maximo, contineri tamen a minimo divinum est” (Nie dać się ograniczyć nawet przez to, co największe, zawierać się jednak nawet w tym, co najmniejsze - Boska to rzecz $)^{47}$. Konsekwentnie Franciszek podaje kolejną grupę świętych, którzy są w stanie pomóc współczesnym ludziom $\mathrm{w}$ realizacji ich powołania do świętości w rzeczywistości, którą tworzą. To św. Tomasz Morus, św. Wincentego à Paulo oraz św. Filip Nereusz, którzy znani są z poczucia humoru. To nie zły humor, a zwy-

${ }^{43}$ Por. GE, 7; por. także: J. Malègue, Pierres noires. Les classes moyennes du Salut, Paris 1958.

${ }^{44} \mathrm{GE}, 12$.

${ }^{45}$ Św. Teresa z Lisieux, Rękopisy autobiograficzne, tłum. A. Bartosz, Kraków 1997, s. 242; por. także: GeE, 72 .

${ }^{46}$ GE, 20.

${ }^{47}$ Por. przypis do GE, 169. 
czajna radość chrześcijańska z towarzyszącym jej poczuciem humoru są widocznym znakiem właściwie rozumianej świętości. Jak przypomina papież „święty jest zdolny do życia pełnego radości i poczucia humoru. Nie tracąc realizmu, oświeca innych pozytywnym i pełnym nadziei duchem" ${ }^{\prime 4}$. Choć zaraz dodaje i przestrzega, że wizja chrześcijańskiej radości daleka jest od zamykania jej w przestrzeniach konsumpcji i indywidualizmu, czyli charakterystycznych cech współczesnego doświadczenia kulturowego ${ }^{49}$.

Wzorce osób świętych proponowanych przez papieża Franciszka ukazują, że święty to nie postać idealistycznego marzenia i wcale nie $\mathrm{z}$ tego świata, ale żyjąca w tym świecie, $\mathrm{w}$ konkretnym czasie, warunkach oraz zewnętrznych okolicznościach, które przez nich pojmowane były jako wielka szansa na ukazanie innym świętości samego Boga. Święty to nie człowiek poruszający się na płaszczyźnie abstrakcji, ale twardo stąpający po ziemi, który już na niej dosięgnął nieba i to często wcale nie poprzez zdobycie wysokogórskich szczytów chrześcijańskich wymagań, nakazów i zakazów, ale przez sumienne, rzetelne i odpowiedzialne wybory moralne dokonywane w szarej realności. Świętość dotyczy bowiem każdego, stąd nie powinna być odczytywana jako ekskluzywny przejaw luksusu wybranych grup, ale jako uniwersalna wartość obejmująca wszystkich. Moralna doskonałość człowieka w takim ujęciu jest perfekcyjną drogą realizacji powołania do świętości.

\section{PRZESZKODY NA DRODZE DO ŚWIĘTOŚCl}

Wśród wielu aktualnych niebezpieczeństw, jakie czyhają na katolika w realizacji jego powołania do świętości, szczególne dwa zostały mocno podkreślone w adhortacji. To gnostycyzm i pelagianizm, którym poświęcony jest cały drugi rozdział dokumentu zatytułowany: „Dwaj subtelni nieprzyjaciele świętości”. Subtelność zagrożeń, w tak sformułowanym paragrafie, posiada istotny ciężar gatunkowy. Oznacza bowiem kwestię wrażliwą, wyrafinowaną, odznaczającą się delikatnością budowy o nieznacznych różnicach, a co za tym idzie, bardzo łatwą do pomylenia

\footnotetext{
${ }^{48}$ GE, 122.

49 Por. GE, 128.
} 
z prawdziwą nauką katolicką. Choć historia powstania obu herezji sięga pierwszych wieków chrześcijaństwa, to jednak dzisiaj pozostają „alarmująco aktualne" ${ }^{50}$, gdyż w zmutowanym kształcie zarażają rzeczywistość naszych czasów i pozostają szkodliwe dla wiary. Cienka i niedostrzegalna granica powoduje, że „wielu chrześcijan, być może nie zdając sobie z tego sprawy, dają się zwieść przez te zwodnicze propozycje" ${ }^{51}$. W związku z niszczycielskim oddziaływaniem gnostycyzm i pelagianizmu na duchowy i moralny rozwój człowieka oraz właściwymi im aspiracjami zmierzającymi do zafałszowania wizji świętości, Franciszek akcentuje konieczność ich unikania. To znaczące przeszkody, które poważnie utrudniają realizację świętości dzisiejszemu człowiekowi. Podobnie jak starożytny Kościół dążył do ich demaskowania i zwalczania, tak i dzisiaj nie można ich tracić z pola widzenia i skutecznie się im przeciwstawiać.

Gnostycyzm został w papieskim dokumencie scharakteryzowany jako jedna „z najgorszych ideologii, ponieważ niesłusznie wywyższając wiedzę lub pewne doświadczenie, uważa swoją szczególną wizję rzeczywistości za doskonałą" "52. Franciszek, odwołując się do wcześniejszego nauczania zawartego w Evangelii gaudium, przypomina, że współcześnie gnostycyzm postrzega wiarę jako „zamkniętą w subiektywizmie, gdzie liczy się jedynie określone doświadczenie albo zbiór idei czy informacji, które - jak się sądzi - przynoszą otuchę i oświecenie, ale gdzie podmiot ostatecznie zostaje zamknięty w immanencji swojego własnego rozumu lub swoich uczuć" 53 . Ma to doniosłe implikacje moralne, gdyż w praktyce życia i działania ludzkiego spotyka się z negacją wszelkich związków ze światem, a przecież papież zachęca w adhortacji do odkrywania i realizacji powołania do świętości właśnie w świecie w jego aktualnych uwarunkowaniach. Świat, według gnozy stanowi przeszkodę w poznawaniu wiedzy (gnoza - gr. $\gamma v \tilde{\omega} \sigma ı \varsigma$ „gnốsis”, czyli wiedza, poznanie) oraz dokonuje podziału między Bogiem, a człowiekiem, którego izoluje i poddaje kontestacji. Choć człowiek i Bóg posiadają tą samą substancję, to jednak Bóg posiada pełną wiedzę, natomiast kształt ludzkiej egzystencji

\footnotetext{
${ }^{50}$ GE, 35.

51 Tamże.

${ }^{52} \mathrm{GE}, 40$.

${ }^{53}$ EG, 94; GE 36.
} 
w świecie uwarunkowany jest brakiem jej poznania ${ }^{54}$. Pogląd absolutyzuje człowieka, który wyłącznie własnym wysiłkiem powinien dołożyć wszelkich starań, aby posiąść wiedzę, mającą właściwości zbawcze. To nie Bóg zbawia, ale człowiek, który zdobywa zbawienie poprzez wtajemniczenie w gnozę. Gnostycka wiedza, zarezerwowana zresztą była dla wybranych. Jedynie istoty duchowe, czyli pneumatycy jako grupa ludzi zajmująca uprzywilejowane miejsce zdolna jest pojąć boską wiedzę. Przywilej ten nie jest dany istotom cielesnym, ziemskim, czyli choikom (grec. $\gamma$ ńıvos „choikos” - ziemski), nazywanymi także hylikami (grec. hýlē „hyle” materia), ani też psychikom, a zatem ludziom psychicznym (grec. $\psi v x \dot{n}$ „psyche” - psychika $)^{55}$. Ponadto gnostycy wyznawali doktrynę dualizmu, pojmowaną jako odwieczna walka dobra ze złem, Boga z Demiurgiem ${ }^{56}$. Dualistyczna wizja świata znajdowała swoje odzwierciedlenie również w koncepcji człowieka, który jako iskra boża został uwięziony w materialnym ciele, jego dusza z kolei poprzez wędrówkę lub ideę „przelewania się" ${ }^{57}$ dąży do uwolnienia $\mathrm{z}$ aresztu świata materialnego. Ciało w ujęciu gnostycznym zawsz przedstawiane było w negatywnym świetle, bardzo często jako więzienie duszy, domostwo, ciemne miejsce ${ }^{58}$. Za tak pojętą antropologią, zbudowaną na bazie antysomatyzmu, stoi określona koncepcja moralności, która przybiera postać dwóch ekstremistycznych postaw. $\mathrm{Z}$ jednej strony mamy do czynienia ze skrajnym ascetyzmem, $\mathrm{z}$ drugiej zaś z libertynizmem moralnym, który wyraża się w całkowitym rozluźnieniu obyczajów. „Pierwsza nakazuje unikać kalania się sprawami świata doczesnego, a druga daje przywilej absolutnej wolności w korzystaniu z dóbr tego świata. Co więcej, gnoza daje wolność w stosunku do wszelkiego porządku i prawa moralnego, które nie jest $z d u c h a " 59$. Ojcowie Kościoła często przypisywali gnostykom niemoralne i często wyuzdane zacho-

${ }^{54}$ Por. S. Warzeszak, Z twórczości Hansa Jonasa (2): Od starożytnej gnozy do wspótczesnego nihilizmu, „Warszawskie Studia Teologiczne” 7 (1994), s. 273.

${ }_{55}$ Por. K. Rudolph, Gnoza. Istota i historia późnoantycznej formacji religijnej, tłum. G. Sowinski, Kraków 1995, s. 84.

${ }_{56}$ Por. M. Ozorowski, Błędne koncepcje dotyczące ciała i płciowości człowieka (I-XVII w.), „Studia nad Rodziną” 1 (1997), s. 64.

57 K. Rudolph, Gnoza, s. 106.

58 Por. tamże.

59 S. Warzeszak, Z twórczości Hansa Jonasa, s. 273. 
wanie wyrażające się w rozpuście, orgiach czy nawet kanibalistycznych ucztach $^{60}$.

W Gaudete et exsultate papież przestrzega przed - przybierającym różne oblicza - współczesnym przejawem gnozy, której „udaje się [...] ujarzmić niektórych zwodniczą fascynacją, ponieważ równowaga gnostyczna jest formalna i we własnym mniemaniu nieskażona. Może przybrać pozory pewnej harmonii lub jakiegoś ładu obejmującego wszystko"61. W czasach współczesnych wpływy gnostycyzmu manifestuje się marginalizacją osób prostych i niewykształconych, zapominając zupełnie o słowach Jezusa, który wielbił Boga Ojca wyznając: „Wysławiam Cię, Ojcze, Panie nieba i ziemi, że zakryłeś te rzeczy [tajemnice królestwa] przed mądrymi i roztropnymi, a objawiłeś je prostaczkom" (Mt 11,25). Gnostycyzm zamyka drogę świętości, rozumianą jako droga moralnej doskonałości przed ewangelicznymi prostaczkami, a gloryfikuje ludzki umysł. Franciszek przypomina, że to co udało nam się osiągnąć na płaszczyźnie naukowej poprzez głębszą formację intelektualną dostępną w Kościele, ma stanowić motywację, aby w jeszcze lepszy sposób odpowiedzieć na miłość Boga ${ }^{62}$. Chrześcijańska wizja świętości ma charakter powszechny i dlatego to nie posiadany poziom intelektualnej znajomości doktryny wiary - bo przecież „to nie wiedza czyni nas lepszymi lub świętymi” ${ }^{63}$ - ale osobista relacja $z$ Jezusem ma decydujące zbawcze znaczenie, $w$ przeciwieństwie do gnostyckiej koncepcji wtajemniczenia zarezerwowanej dla wybranych. Poza tym świętość nie ma nic wspólnego z zerwaniem ze światem (jak życzyliby sobie gnostycy), w którym prowadzimy życie, każdego dnia podejmując je jako misję. Znajduje ona swój „pełny sens w Chrystusie i można ją zrozumieć jedynie rozpoczynając od Niego"64.

Drugim wrogiem świętości w obecnych czasach jest pelagianizm, w którym „to już nie inteligencja [...], ale wola”65 zajmuje decydujące miejsce. Warto przypomnieć, że podstawą tej herezji, głoszonej przez brytyjskiego mnicha Pelagiusza, było przekonanie, „że łaska nie jest czło-

\footnotetext{
${ }^{60}$ Por. M. Ozorowski, Błędne koncepcje, s. 65.

${ }^{61} \mathrm{GE}, 38$.

62 Por. GE, 45.

${ }^{63} \mathrm{GE}, 47$.

${ }^{64} \mathrm{GE}, 20$.

${ }^{65} \mathrm{GE}, 48$.
} 
wiekowi potrzebna do zbawienia"66. Miało to swoje negatywne reperkusje w odniesieniu do moralności, bowiem odrzucając aspekt nadprzyrodzony twierdzono, że człowiek może prowadzić bezgrzeszne życie, że „jest zdolny do działania moralnie dobrego i do zbawienia bez pomocy łaski" ${ }^{67}$, a jedynie siła wolnej woli. Chrystus, którego wcielenie i zmartwychwstanie podważano, wskazywany był wprawdzie jako przykład do naśladowania, ale jedynie w postacie moralnego wzorca, danego ludziom przez Boga Ojca, przypatrującego się z oddali czy ludzie się nim posiłkują. W rzeczywistości prowadziło to do zakwestionowania odkupieńczego sensu dzieła Chrystusa. Błędnie podkreślając wysokie właściwości natury ludzkiej, stawiano ludziom wysokie wymagania moralne i uznawano, że dobre uczynki wystarczają do osiągnięcia zbawienia, pomijano przy tym aspekt słabości ludzkiej natury, co obecnie - zdaniem papieża - przybiera postać braku „szczerego, bolesnego i modlitewnego uznania naszych ograniczeń"68. Ponadto, celując wprost w główne założenia pelagianizmu, Franciszek zaznacza, „że nie jesteśmy usprawiedliwieni przez nasze uczynki lub nasze wysiłki, ale przez łaskę Pana, który podejmuje inicjatywę" ${ }^{69}$. Dokonując charakterystyki współczesnej mentalności pelagiańskiej, papież utożsamia ją z tą grupą ludzi, którzy choć w słodkich wystąpieniach mówi o łasce Bożej, to jednak „w ostateczności liczą tylko na własne siły i stawiają siebie wyżej od innych, ponieważ zachowują określone normy, albo ponieważ są niewzruszenie wierni pewnemu katolickiemu stylowi czasów minionych"70. W rezultacie neopelagianie wykazują skłonności do pogardzania wątłymi i grzesznymi, nie uznając ludzkiej słabości. Umiłowanie własnej doskonałości oraz siły ludzkiej woli finalnie przekłada się „na egocentryczne i elitarystyczne samozadowolenie"71 i prowadzi do odrzucenia prawdziwej miłości oraz wiarygodnej świętości.

${ }^{66}$ R.T. Ptaszek, Początki sekt w Europie, „Doctrina. Studia społeczno-polityczne” 2 (2005), s. 350.

${ }^{67}$ J. Pryszmont, Patrystyczna myśl moralna, „Studia Theologica Varsaviensia” 19 (1981) 2, s. 147.

${ }^{68} \mathrm{GE}, 50$.

${ }^{69} \mathrm{GE}, 52$.

70 EG, 94; GE 49.

${ }^{71}$ GE, 57. 
Dokonana w papieskim dokumencie charakterystyka dwóch subtelnych wrogów świętości w obecnym świecie ukazuje niebezpieczeństwa, z jakim dzisiaj w realizacji moralnej doskonałości spotyka się wierny katolik. Nowe formy gnostycyzmu i pelagianizmu przejawiają swoje groźne oblicze przede wszystkim w przeszkodach i utrudnieniach stawianych na drodze do świętości, często zatrzymując na niej.

\section{BŁOGOSŁAWIEŃSTWA DROGOWSKAZEM NA DRODZE DO ŚWIĘTOŚCl}

Na drodze prowadzącej do świętości, wśród pluralizmu proponowanych do podjęcia propozycji, nierzadko złudnych - jak zaakcentowane wyżej formy gnostycyzmu czy pelagianizmu przybierające dzisiaj nowy kształt - człowiek potrzebuje wyraźnych oraz jasnych znaków. Takie właśnie podaje papież Franciszek, gdy odwołuje się do błogosławieństw zawartych w „Kazaniu na Górze, stanowiącym magna charta ewangelicznej moralności”72. Jak wyjaśnia papież z Argentyny to w błogosławieństwach odbija się rzeczywiste „oblicze Mistrza” ${ }^{3}$. W tym papieskim stwierdzeniu pobrzmiewają słowa znakomitego teologia moralisty, ojca Servaisa Théodora Pinckaersa, który pisał:

Kazanie [na Górze] odsłania w sposób dyskretny uczucia, duszę i oblicze duchowe Chrystusa. Możemy więc słowa Kazania na Górze odnieść do samego Chrystusa i zobaczyć, jak On je wypełniał w swoim życiu i jaką cechę Jego duszy one odkrywają. Kazanie na Górze jest najwierniejszym portretem Chrystusa, jaki możemy otrzymać, a przez to najwłaściwszym wzorem życia, jaki może być nam zaproponowany. [...] Możemy w nim rozpoznać cechy życia i oblicze Chrystusa, które Duch Święty pragnie w nas odbić, tak, aby uczynić nas na obraz i podobieństwo Syna Bożego ${ }^{74}$.

Summus Pontifex przypomina, że do ukazywania prawdziwego oblicza Chrystusa poprzez osobistą świętość wszyscy jesteśmy wezwani

${ }^{72}$ Jan Paweł II, Encyklika o niektórych podstawowych problemach nauczania moralnego Kościoła „Veritatis splendor”, 75. Odtąd skrót: VS.

${ }^{73} \mathrm{GE}, 63$.

74 S.Th. Pinckaers, Szczęście odnalezione, tłum. P. Siejkowski, Poznań 1998, s. 21. 
„W życiu codziennym”75. Doskonałość moralna człowieka, a w rezultacie jego świętość, wypływa z bycia w świetle Chrystusa, który finalnie jest ostateczną normą moralną każdego chrześcijanina. Zostawiając dzisiejszemu człowiekowi błogosławieństwa, „Jezus wyjaśnił z całą prostotą, co to znaczy być świętymi" ". Ponadto Chrystus jako centrum i podstawa wyborów moralnych ma stać się przykładem, na którym wszyscy Jego uczniowie powinni się wzorować ${ }^{77}$. W takim znaczeniu już Jan Paweł II pisał, że „naśladowanie Chrystusa jest pierwotnym i najgłębszym fundamentem chrześcijańskiej moralności”78. Droga świętości ujęta w ewangelicznych błogosławieństwach nie jest wyimaginowaną mrzonką, ale rzeczywistym wskazaniem Chrystusa ukonstytuowanym w ramach życiowych problemów ubóstwa, smutku, cichości, pragnienia sprawiedliwości, miłosierdzia, czystości serca, pokoju i znoszonych prześladowań (Por. Mt 5,3-12), z którymi człowiek XXI wieku zmaga się w całej rozciągłości swojej doczesnej egzystencji. Dążenie do tego, aby naśladować Jezusa nie jest jednak ślepym kopiowaniu słów i czynów Chrystusa, ale wyraża się poprzez pełna integrację swojego działania z postępowaniem Mistrza i upodobnieniem się do Niego w miłości. Podążanie człowieka w ślad za Jezusem stanowi jego osobistą odpowiedź na wezwanie do tego, aby stawać się doskonalszym poprzez implementację teologicznomoralnego bogactwa kryjącego się w błogosławieństwach. Każde ewangeliczne wezwanie do prawdziwego szczęścia przybiera postać nieomylnego drogowskazu, który prosto i dokładnie prowadzi wierzącego człowieka na krętej ścieżce aktualnych wyzwań, stawianych mu przez świat. Obecnie bowiem człowiek ryzykuje poddaniem się $\mathrm{z}$ jednej strony wszelkim przejawom moralnego relatywizmu, $\mathrm{z}$ drugiej zaś obiektywizmu, stąd wskazania zawarte w Kazaniu na Górze są ni-

75 GE, 63.

76 Tamże.

$77 \mathrm{~W}$ rozumieniu nauki Kościoła rzymskokatolickiego, w przeciwieństwie do herezji pelagianizmu, która dostrzegała w Chrystusie jedynie moralny przykład dla człowieka, ale kwestionowała Jego Wcielenie i Zmartwychwstanie, ostatecznie zmierzając ku zaprzeczeniu dzieła odkupienia człowieka w Chrystusie. Por. A. Filipowicz, Josef Fuchs. Kroczyć śladami Chrystusa, w: Leksykon wielkich teologów XX/XXI wieku, t. II, red. J. Majewski, J. Makowski, Warszawa 2004, s.127.

78 VS, 19. 
czym zaaplikowane przez boskiego Lekarza antidotum przeciw owym zagrożeniom.

W naszym wieku wielu może paść ofiarą zbyt sceptycznego nastawienia i powściągliwości, czy rzeczywiście nakreślona przez Chrystusa w błogosławieństwach droga realizacji powołania do świętości jest możliwa, czy świat z promowanymi przez niego rozproszeniami nie daje wrażenia zbytniego ciężaru ich wypełnienia? Czy nakazy moralne stawiane przez Chrystusa nie są zbyt wygórowane i nie przewyższają możliwości współczesnych wierzących? Świat zachęca do zupełnie „innego stylu życia"79, diametralnie różniącego się od tego, który został nakreślony na kartach Ewangelii. Proponowana przez współczesne nurty i poglądy wizja życia bazuje na przyjemności, łatwości, hedonistycznym konsumpcjonizmie, indywidualizmie oraz pozornej powierzchowności, gdzie katolicka moralność schodzi na dalszy plan. W takich warunkach szybko można popaść w pesymizm. Wątpliwości tego rodzaju wyraża także Servais Théodor Pinckaers:

Czyż Kazanie nie ukazuje nam tak wzniosłych i subtelnych nakazów moralnych, że daleko przekracza ono możliwości zwykłych ludzi oraz $\mathrm{w}$ wielu punktach jest trudne do zastosowania w praktyce? Czy nie stawia nas ono wobec czegoś niemożliwego, jakby przed szczytem góry, który znika w obłokach i pozostaje niedosiężny dla naszych słabych sił? ${ }^{80}$

W swojej zachęcie papież przychodzi z jednoznaczną odpowiedzią: „możemy nimi żyć”81, pamiętając o asystencji Ducha Świętego, który przeniknąwszy człowieka uwalnia go od słabości grzechu i otwiera na słowa Jezusa, a te uderzają celnie w punkt, prowokują i wzywają do rzeczywistej przemiany życia ${ }^{82}$. Błogosławieństwa, nazwane przez Franciszka „dowodem tożsamości chrześcijanina" ${ }^{33}$, w prezentowanym wzniosłym ideale moralnym, zawierają najdoskonalszy program realizacji świętości. Ten, kto podejmuje wskazaną przez nie drogę realizacji powołania do świętości

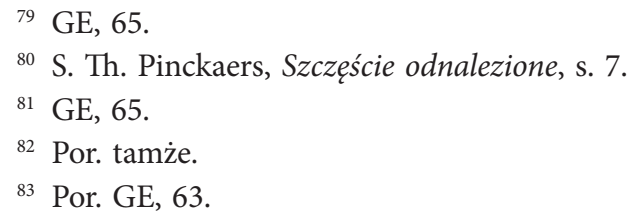


daje jednocześnie wyraz dojrzałej oraz moralnej doskonałości. Chrystus zostawiając tak wysokie wymagania moralne, równocześnie obdarza łaską Ducha Świętego, dzięki której wierny jest w stanie wypełnić swoją misję. Na przestrzeni wieków, aż po dziś wyraźnie widać, „że dzięki otwartości człowieka na tę Bożą moc, na pozór niewykonalne przesłanie z Góry Błogosławieństw wydało niezliczone owoce świętości, na wzór ewangelicznego stokrotnego plonu (por. Mt 13, 8)"84. Trudno odczytywać osiem błogosławieństw jedynie $\mathrm{w}$ kategoriach określonego zbioru powinności etycznych, są to raczej konkretne postawy moralne, stanowiące fundament życia prawdziwego ucznia Chrystusa i decydujące o nowym wymiarze wzajemnych relacji i odniesień. Franciszek nie pozostawia złudzeń, na czym miałaby polegać droga do świętości współczesnego człowieka: to życie w Chrystusie, który w Kazaniu na Górze wskazuje, że realizacja świętości to podążanie drogą w kierunku ukazanym przez błogosławieństwa.

\section{ZAKOŃCZENIE}

Gaudete et exsultate stanowi zbiór praktycznych porad dla człowieka współczesnego pokazując mu, jak realizować powołanie do świętość w dzisiejszym świecie. Wśród wielu zagrożeń i problemów, z jakim aktualnie mierzy się Kościół, zagadnienie powszechnego powołania do świętości w jego wymiarze moralnym przybiera postać kluczowego elementu. Ostatecznie każdy wierzący, na mocy sakramentu chrztu, wezwany jest do tego, aby w świętości odkrywać zasadnicze „ukierunkowanie oraz pewność dobrej przyszłości”" ${ }^{\prime 5}$. A zatem niezależnie od tego, czy ktoś należy do hierarchii, czy też jest wiernym świeckim, wszyscy są wezwani do świętości, gdyż jest ona „najpiękniejszym obliczem Kościoła”86 i jednocześnie prowadzi do życia autentycznego i w pełni szczęśliwego. Podążając w tym kierunku w codzienności, człowiek stawia kroki na drodze prawdziwego życia, jakie zostało nakreślone przez Jezusa w ewangelicznych błogosławieństwach. Unikając fałszywych form, dających złudne i ulotne szczęście

${ }^{84}$ J. Bramorski, Błogosławieństwa jako program moralności chrześcijańskiej w ujęciu biblijnym, „Studia Gdańskie” 21 (2007), s. 49.

${ }^{85}$ Franciszek, Encyklika o wierze „Lumen fidei”, 43.

86 GE, 9. 
- proponowanych w obecnej dobie przez hedonistyczny konsumpcjonizm - oraz żyjąc Ewangelią na co dzień, każdy jest w stanie rozeznać właściwą sobie drogę świętości. Ukazane $\mathrm{w}$ adhortacji oblicze świętości to życie moralne przepełnione cnotą miłości oraz bycie świadkiem Chrystusa w rzeczach spełnianych każdego dnia. Właśnie tak realizuję się świętość, która staje się wyrazem moralnej doskonałości człowieka.

\section{BIBLIOGRAFIA}

\section{Źródło podstawowe}

Franciszek, Adhortacja apostolska o powołaniu do świętości w świecie wspótczesnym „Gaudete et exsultate", Rzym 2018.

\section{Nauczanie soborowe}

Sobór Watykański II, Konstytucji dogmatyczna o Kościele „Lumen gentium”, Rzym 1964.

\section{Nauczanie papieskie}

Pawła VI, Adhortacja apostolska o ewangelizacji w świecie współczesnym „Evangelii nuntiandi", Rzym 1975.

Pawła VI, Przemówienie do członków „Concilium de Laicis”, AAS 66 (1974), s. 567-570. Jan Paweł II, Encyklika o niektórych podstawowych problemach nauczania moralnego Kościoła „Veritatis splendor”, Rzym 1993.

Jan Paweł II, List apostolski „Novo millennio ineunte”, Watykan 2001.

Jan Paweł II, Powołanie do petni życia chrześsijańskiego, w: Jan Paweł II, Dzieła Zebrane, t. XV, Kraków 2009, s. 414-415.

Benedykt XVI, Wszyscy święci papieża, „L'Osservatore Romano” wyd. pol. 334 (2011) 6, s. 52.

Franciszek, Encyklika o wierze „Lumen fidei”, Rzym 2013.

Franciszek, Adhortacja apostolska o głoszeniu Ewangelii we wspótczesnym świecie „Evangelii gaudium", Rzym 2013.

Franciszek, Adhortacja apostolska o miłości w rodzinie „Amoris laetitia”, Rzym 2016.

Franciszek, $Z$ ludem na ramionach. Homilia wygtoszona podczas Mszy św. Krzyżma, „L'Osservatore Romano” wyd. pol. 371 (2015) 5, s. 34-35.

\section{Literatura przedmiotu i pomocnicza}

Bramorski J., Błogostawieństwa jako program moralności chrześcijańskiej w ujęciu biblijnym, „Studia Gdańskie” 21 (2007), s. 20-50.

Demmer K., Wprowadzenie do teologii moralnej, tłum. A. Baron, Kraków 1996.

Filipowicz A., Josef Fuchs. Kroczyć śladami Chrystusa, w: Leksykon wielkich teologów XX/XXI wieku, t. II, red. J. Majewski, J. Makowski, Warszawa 2004, s.126-132. 
Kolbe M.M., Nasze radości i niedociagnięcia, w: Konferencje świętego Maksymiliana Marii Kolbego, red. J.R. Bar, Niepokalanów 2009, s. 92-94.

Ozorowski M., Błędne koncepcje dotyczące ciała i płciowości człowieka (I-XVII w.), „Studia nad Rodziną" 1 (1997), s. 63-72.

Pinckaers S.Th., Szczęście odnalezione, tłum. P. Siejkowski, Poznań 1998.

Pryszmont J., Patrystyczna myśl moralna, „Studia Theologica Varsaviensia” 19 (1981) 2, s. $121-155$.

Ptaszek R.T., Początki sekt w Europie, „Doctrina. Studia społeczno-polityczne” 2 (2005), s. 345-351.

Rudolph K., Gnoza. Istota i historia późnoantycznej formacji religijnej, tłum. G. Sowinski, Kraków 1995.

Św. Teresa z Lisieux, Rękopisy autobiograficzne, tłum. A. Bartosz, Kraków 1997.

Warzeszak S., Z twórczości Hansa Jonasa (2): Od starożytnej gnozy do współczesnego nihilizmu, „Warszawskie Studia Teologiczne” 7 (1994), s. 269-278.

Wróblewski P., Świętość fundamentem odnowy Kościoła: powszechne powołanie do świętości, „Łódzkie Studia Teologiczne” 24 ( 2015) 3, s. 161-174. 